\title{
PENGARUH PAKAN YANG BERBEDA TERHADAP PERTUMBUHAN BENIH IKAN GABUS (Channa gacua)
}

\author{
Fariedah, F, Widodo, M. S. \\ Jurusan Manajemen Sumberdaya Perairan, Program Studi Budidaya Perairan, \\ Fakultas Perikanan dan Ilmu Kelautan, Universitas Brawijaya Malang \\ fanifariedah@ub.ac.id
}

\begin{abstract}
The purpose of this research was to know the suitable food for snake head fry rearing. This research used experimental method with completely randomized design with three treatment: A (used Artemia sp.), B (used Daphnia sp.) and C (used Tubifex sp.), each treatment was replicated 3 replication. Major parameters was growth rate and specific growth rate while minor parameters was temperature, dissolved oxygen and $\mathrm{pH}$. The result showed that treatment $C$ which used Tubifex as feed resulted the highest growth rate with $1.25 \% / d a y$ and also the highest of spesific growth rate was resulted from treatment $C$ which used Tubifex as feed with $1.39 \% /$ day. This was caused that protein content in Tubifex was the highest than in Artemia and Daphnia (63.05\%). Protein was the major nutrient that affected fish growth performance. Protein supplied essential and non essential acid amino that needed to muscle formation and enzimatic function, beside that protein also had a role to energy availability preservation. The result of water quality measurement showed that water quality was suitable for snake head fry growth. Water quality toward that temperature between $20^{\circ} \mathrm{C}-27^{\circ} \mathrm{C}, \mathrm{DO} 3-4,50 \mathrm{mg} / \mathrm{L}$ and $\mathrm{pH}$ range from 5 to 8.42

Keywords: Artemia, Daphnia, Growth Rate, Snake Head, Tubifex
\end{abstract}

\section{PENDAHULUAN}

Salah satu upaya yang bisa dilakukan untuk meningkatkan hasil produksi perikanan adalah budidaya perikanan. Usaha budidaya perikanan sampai saat ini sudah menunjukkan perkembangan yang pesat. Dalam usaha budidaya perikanan, tujuan utama yang ingin dicapai adalah untuk memperoleh ikan dengan ukuran tertentu dalam jumlah yang banyak dengan menekan biaya sekecil mungkin (Mulyadi, dkk., 2010).

Pembenihan dan pembesaran merupakan usaha budidaya yang dapat dikembangkan. Pembesaran ikan Gabus (Channa gacua) merupakan usaha budidaya yang memiliki nilai potensial untuk dikembangkan karena permintaan komoditas ikan Gabus setiap tahun terus meningkat (Kartamihardja, 1994). Ikan Gabus dimanfaatkan karena kandungan Albumin yang memiliki berbagai manfaat bagi penderita hipoalbumin dan penyembuhan luka baik luka pascaoperasi maupun luka bakar (Ulandari, 2011).

Ikan Gabus dimasukkan dalam kelompok ordo Labyrinthycy yang memiliki ciri bagian tubuh dan kepala ditutupi sisik. Badan berbentuk bulat memanjang pada bagian depan dan memipih tegak ke arah belakang sehingga ikan ini dikenal dengan sebutan ikan kutuk berkepala ular (snake head). Ikan Gabus adalah sejenis ikan buas yang hidup di perairan tawar (Bijaksana, 2010).

Menurut Ansar dan Muslimin (2010), ikan Gabus merupakan ikan pemangsa atau ikan predator. Pada saat larva, ikan Gabus mampu memakan berbagai jenis makanan seperti daphnia, sedangkan ketika dewasa ikan Gabus akan memakan udang air tawar, ikan kecil, katak, kepiting dan cacing serta berbagai serangga yang ada di perairan (Bijaksana, 2010).

Pakan yang baik adalah pakan yang mempunyai nilai gizi yang tinggi, mudah dicerna, mudah diperoleh, murah dan tidak mengandung racun. Bukaan mulut ikan dan umur ikan akan menentukan jenis pakan yang akan diberikan, dimana semakin kecil bukaan mulut maka ukuran pakan yang diberikan juga semakin kecil.

Pertumbuhan diartikan sebagai perubahan ukuran panjang dan berat dalam jangka waktu yang telah ditentukan. Pertumbuhan pada ikan didefinisikan sebagai hubungan antara pertambahan bobot tubuh pada waktu tertentu yang bergantung pada spesies. Faktor-faktor internal yang mempengaruhi pertumbuhan diantaranya adalah spesies dan jenis kelamin sedangkan faktor eksternal yang mempengaruhi pertumbuhan adalah kualitas pakan dan 
lingkungan. Tujuan dari penelitian ini yaitu untuk mengetahui jenis pakan yang baik untuk pertumbuhan benih ikan Gabus (C. gacua).

\section{METODE PENELITIAN}

Alat dan bahan

Peralatan yang digunakan untuk penelitian tentang pengaruh pemberian pakan yang berbeda terhadap laju pertumbuhan dan ikan Gabus (C. gacua) adalah sebagai berikut: toples, seser, DO meter, $\mathrm{pH}$ meter, nampan, serbet, timbangan analitik, akuarium ikan Gabus, beacker glass, selang aerator, batu aerasi, gelas ukur, tabung corong, termometer, bak, toples penampungan artemia, akuarium daphnia, kulkas, selang sifon, selang besar pengisian, gayung, pisau, telenan, gelas ukur kecil, jaring dan heater.

Bahan yang digunakan dalam penelitian tentang pengaruh pemberian pakan yang berbeda terhadap laju pertumbuhan ikan Gabus (C. gacua) adalah sebagai berikut: Cacing sutra (Tubifex sp), Daphnia, Air laut, Artemia, ikan Gabus (C. gacua) sejumlah 180 ekor ukuran 3 $5 \mathrm{~cm}$.

\section{Cara Kerja}

Metode penelitian yang digunakan adalah metode eksperimental dengan rancangan acak lengkap dengan tiga perlakuan yaitu perlakuan A dengan menggunakan artemia, B menggunakan daphnia dan $\mathrm{C}$ menggunakan cacing sutera, dengan ulangan tiga kali pada masing-masing perlakuan.

Penelitian dimulai dengan penebaran benih ikan Gabus yang sudah ditimbang berat badannya (W0) ke dalam akuarium yang telah disiapkan sebelumnya. Pemberian pakan dilakukan secara adlibitum dimana pemberian secara terus menerus sampai ikan kenyang dan tidak mau makan lagi. Pakan diberikan dengan frekuensi 3 kali sehari yaitu pagi pukul 09:00, sore pukul 14:00 dan malam pukul 21:00. Dilakukan penimbangan berat akhir ikan Gabus sebagai (Wt). Dilakukan pengukuran kualitas air meliputi $\mathrm{pH}$, suhu dan DO setiap pagi dan sore. Dalam penelitian ini pergantian air dilakukan setiap hari. Pergantian air dilakukan dengan mengurangi air sebanyak $10 \%-30 \%$ air dari volume air awal dan ditambahkan air baru sesuai air yang dikeluarkan tujuannya untuk mengurangi toxic dari feses.

\section{Parameter Utama}

Parameter utama yang diuji dalam penelitian ini yaitu meliputi pertumbuhan ikan yaitu laju pertumbuhan spesifik (SGR) dihitung dengan rumus:

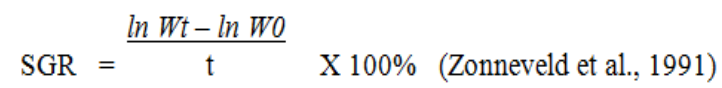

Keterangan :

SGR = Laju pertumbuhan berat spesifik $(\% /$ hari)

$\mathrm{Wt}=$ Bobot rata-rata pada akhir penelitian

(gr)

$\mathrm{W} 0=$ Bobot rata-rata pada awal penelitian

(gr)

$\mathrm{t} \quad=$ Waktu penelitian

Laju pertumbuhan panjang harian yang akan dihitung dengan rumus sebagai berikut:

$$
\frac{\ln W t-\ln W 0}{\mathrm{t}} \quad \mathrm{X} 100 \%
$$

Keterangan :

Lt = Panjang rata-rata pada hari ke-t

L0 = Panjang rata-rata pada hari ke-0

$\mathrm{t}=$ Hari penelitian

\section{Parameter Penunjang}

Parameter penunjang dalam penelitian ini adalah kualitas air yang meliputi pengukuran suhu, $\mathrm{pH}$ dan DO (Disolved Oxygen) yang diukur setiap hari selama penelitian pada pukul 05.00 dan 14.00 WIB.

\section{Analisis Data}

Data yang diperoleh dari hasil penelitian dianalisa secara statistik dengan menggunakan Analysis of Variance (ANOVA) sesuai dengan rancangan yang digunakan, yaitu Rancangan Acak Lengkap (RAL). Apabila dari data sidik ragam diketahui bahwa perlakuan menunjukkan pengaruh yang berbeda nyata (significant) atau berbeda sangat nyata (highly significant), maka untuk membandingkan nilai antar perlakuan dilanjutkan dengan uji BNT (beda nyata terkecil).

\section{HASIL DAN PEMBAHASAN \\ Laju Pertumbuhan Panjang Harian}

Rata-rata laju pertumbuhan panjang benih ikan Gabus dari hasil penelitian pengaruh pemberian pakan yang berbeda selama pemeliharaan disajikan pada Tabel 1 . 
Tabel 1. Data Laju Pertumbuhan Panjang Ikan Gabus (Channa gacua) (\%/hari)

\begin{tabular}{cccccc}
\hline Perlakuan & \multicolumn{3}{c}{ Ulangan } & Total & $\begin{array}{c}\text { Rata-rata } \pm \\
\text { STDV }\end{array}$ \\
\cline { 2 - 4 } & $\mathbf{1}$ & $\mathbf{2}$ & $\mathbf{3}$ & & \\
\hline A & 0.87 & 1.01 & 0.91 & 2.78 & $0.93 \pm 0.007$ \\
\hline B & 0.64 & 0.53 & 0.61 & 1.79 & $0.60 \pm 0.05$ \\
\hline C & 1.21 & 1.27 & 1.28 & 3.76 & $1.25 \pm 0.003$ \\
\hline
\end{tabular}

Berdasarkan pada Tabel 1. didapatkan hasil rata-rata pada perlakuan $\mathrm{A}$ sebesar 0,93 $\%$ /hari, B sebesar 0,60 \%/hari, dan C sebesar 1,25\%/hari. Menurut Tabel 1 didapatkan hasil rata-rata tertinggi pada perlakuan $\mathrm{C}$ (Tubifex sp.) dan hasil rata-rata terendah pada perlakuan B (Daphnia sp.). Uji sidik ragam dilakukan untuk mengetahui ada tidaknya perbedaan yang signifikan terhadap laju pertumbuhan panjang harian ikan Gabus diantara perlakuan.

Berikut ini hasil sidik ragam panjang ikan pada pemeliharaan, disajikan pada (Tabel 2.).

Tabel 2. Tabel Sidik Ragam Laju Pertumbuhan Panjang Ikan Gabus (Channa Gacua)

\begin{tabular}{ccccccc}
\hline $\begin{array}{c}\text { Sumber } \\
\text { Keragaman }\end{array}$ & db & JK & KT & F Hit & F 5\% & F1\% \\
\hline Perlakuan & 2 & 0.650021 & 0.32501 & $109.194^{* \star}$ & 5.143 & 10.92 \\
Acak & 6 & 0.0179 & 0.002976 & & & \\
Total & 8 & 0.6679 & & & & \\
\hline
\end{tabular}

Keterangan: ${ }^{* *}=$ berbeda sangat nyata

Berdasarkan tabel sidik ragam diperoleh nilai $\mathrm{F}$ hitung lebih besar daripada $\mathrm{F}$ tabel (109.194>10.92) sehingga dapat disimpulkan bahwa pemberian pakan yang berbeda berpengaruh sangat nyata terhadap laju pertumbuhan ikan Gabus (Channa gacua). Uji BNT dilakukan untuk mengetahui jenis pakan mana yang menghasilkan panjang yang berbeda sangat nyata dengan yang lain.

Berikut ini hasil uji BNT laju pertumbuhan panjang pada pemeliharaan, disajikan pada (Tabel 3.)
Tabel 3. Uji BNT Laju Pertumbuhan Panjang Ikan Gabus (Channa gacua)

\begin{tabular}{cccccc} 
Perlakuan & Rata-rata & B & A & C & Notasi \\
\cline { 3 - 5 } & & 0.60 & 0.93 & 1.25 & \\
B & 0.60 & - & & & a \\
A & 0.93 & $0.33^{\star \star}$ & - & & b \\
C & 1.25 & $0.66^{\star \star}$ & $0.33^{\star \star}$ & - & c
\end{tabular}

Keterangan:

$*$ = berbeda nyata

** = berbeda sangat nyata

ns $=$ tidak berbeda nyata

Berdasarkan hasil uji BNT pada tabel di atas terlihat bahwa notasi antara masing-masing perlakuan berbeda, hal ini menunjukkan bahwa tiap-tiap perlakuan memberikan pengaruh yang berbeda, dimana pada perlakuan B (Daphnia sp) tidak berbeda nyata atau non signifikan, perlakuan A (Artemia sp), C (Tubifex sp) menunjukkan hasil berbeda sangat nyata.

Analisis proksimat yang dilakukan pada cacing sutera (Tubifex sp) menunjukkan bahwa cacing sutera mengandung 12,78 \% abu, 0,40 \% serat kasar, 17,34 \% lemak kasar, dan 63,05 $\%$ protein kasar. Berdasarkan hasil proksimat tersebut dapat diketahui bahwa kandungan protein pada cacing sutera cukup tinggi untuk memenuhi kebutuhan pertumbuhan ikan Gabus karena protein adalah salah satu nutrisi yang diperlukan oleh ikan untuk membentuk jaringan baru dan menggantikan jaringan yang rusak pada saat pertumbuhan (Meyer and Fracalossi, 2004).

Protein merupakan salah satu nutrien yang sangat penting yang dibutuhkan dalam pertumbuhan ikan. Ikan membutuhkan 40 - 60 $\%$ protein dalam pakannya untuk dikonversi dari pakan menjadi jaringan tubuh (Craig and Helfrich, 2009). Hal ini menunjang pernyataan yang diungkapkan oleh Jobling (1994) bahwa ikan-ikan karnivor akan mengalami pertumbuhan yang optimum tersedia 40-50\% protein di dalam pakannya.

Pertumbuhan panjang harian ikan Gabus yang diberi pakan berupa Artemia sebesar $0.93 \pm 0.007$, karena protein kasar yang dikandung Artemia lebih rendah jika dibandingkan dengan protein kasar yang dikandung cacing sutera (Tubifex sp) yaitu 50,84 \%. Kandungan nutrisi Artemia sp. menurut analisis proksimat yang telah dilakukan adalah 21,85\% Abu; 5,84\% serat 
kasar; 14,36 \% lemak kasar; dan 50,84 \% protein kasar.

Kandungan protein yang dikandung Artemia sebesar 50,84 \% masih berada dalam nilai optimum yang disarankan untuk menunjang pertumbuhan ikan karnivora seperti ikan Gabus yaitu antara 40 - 50 \% (Jobling, 1994). Namun dengan kandungan protein yang lebih tinggi yang dikandung oleh pakan akan memberikan performa pertumbuhan yang lebih bagus seperti pertumbuhan yang dihasilkan oleh ikan Gabus yang diberi pakan Cacing sutera karena untuk bisa terkonversi dari pakan menjadi jaringan tubuh ikan memerlukan kandungan protein sampai $60 \%$ (Craig and Helfrich, 2009).

Hasil analisis proksimat yang dilakukan pada Daphnia sp menunjukkan bahwa Daphnia sp. mengandung 28,17\% Abu; 9,38 \% serat kasar; 7,22 \% lemak kasar; dan 51,15\% protein kasar. Pangkey (2009) mengemukakan bahwa makanan yang digunakan sebagai pakan Daphnia berpengaruh terhadap kandungan nutrisinya.

\section{Laju Pertumbuhan Spesifik (Specific Growth Rate)}

Dari hasil pengamatan selama perlakuan didapatkan data laju pertumbuhan spesifik ikan Gabus pada pemeliharaan, disajikan pada (Tabel.4).

Tabel 4. Data Rata-rata laju pertumbuhan spesifik ikan Gabus (Channa gacua) (\%/hari)

\begin{tabular}{cccccc}
\hline Perlakuan & \multicolumn{3}{c}{ Ulangan } & Total & $\begin{array}{c}\text { Rata-rata } \pm \\
\text { STDV }\end{array}$ \\
\cline { 2 - 4 } & $\mathbf{1}$ & $\mathbf{2}$ & $\mathbf{3}$ & & \\
\hline A & 0.72 & 0.75 & 0.75 & 2.21 & $0.74 \pm 0.02$ \\
\hline B & 0.54 & 0.42 & 0.40 & 1.36 & $0.45 \pm 0.08$ \\
\hline C & 1.25 & 1.31 & 1.59 & 4.16 & $1.39 \pm 0.19$
\end{tabular}

Berdasarkan data pada Tabel 4. menunjukkan bahwa pemeliharaan ikan Gabus pada perlakuan A didapatkan hasil rata-rata laju pertumbuhan tertinggi adalah pada perlakuan $\mathrm{C}$ sebesar 1,39\%/hari, kemudian perlakuan A sebesar $0,74 \%$ /hari, dan laju pertumbuhan terendah diperoleh dari perlakuan B sebesar $0,45 \% /$ hari.

Uji sidik ragam dilakukan untuk mengetahui apakah ada perbedaan di antara perlakuan terhadap laju pertumbuhan harian ikan Gabus (Channa gacua). Hasil sidik ragam ditunjukkan pada Tabel 5.
Tabel 5. Sidik Ragam Laju Pertumbuhan

Spesifik Ikan Gabus (Channa gacua)

\begin{tabular}{ccccccc}
\hline $\begin{array}{c}\text { Sumber } \\
\text { Keragaman }\end{array}$ & db & JK & KT & F Hit & F 5\% & F1\% \\
\hline Perlakuan & 2 & 1.369376 & 0.684688 & $50.4213^{\text {** }}$ & 5.14 & 10.92 \\
Acak & 6 & 0.0815 & 0.013579 & & & \\
Total & 8 & 1.4509 & & & &
\end{tabular}

Keterangan: $* *=$ berbeda sangat nyata

Hasil sidik ragam pada Tabel 5 menunjukkan bahwa nilai $\mathrm{F}$ hitung lebih besar dari $\mathrm{F}$ tabel $1 \%$ yang berarti berbeda sangat nyata atau bahwa perlakuan pemberian pakan yang berbeda pada ikan Gabus memberi pengaruh terhadap laju pertumbuhan.

Uji BNT dilakukan untuk mengetahui pakan mana yang memberikan pengaruh yang terbaik. Berikut ini disajikan hasil uji lanjut BNT laju pertumbuhan spesifik pemeliharaan ikan Gabus (Tabel 6.)

Tabel 6. Hasil Uji BNT Laju Pertumbuhan

\begin{tabular}{cccccc}
\multicolumn{5}{c}{ Spesifik Ikan Gabus (Channa gacua) } \\
Perlakuan & Rata-rata & B & A & C & Notasi \\
\cline { 3 - 5 } & & 0.45 & 0.74 & 1.39 & \\
\hline B & 0.45 & - & & & a \\
A & 0.74 & $0.29^{\star *}$ & - & b \\
C & 1.39 & $0.94^{\star *}$ & $0.65^{\star *}$ & - & c
\end{tabular}

Keterangan:

$$
\begin{aligned}
* & =\text { berbeda nyata } \\
* * & =\text { berbeda sangat nyata } \\
\mathrm{ns} & =\text { tidak berbeda nyata }
\end{aligned}
$$

Pada Tabel di atas, dapat disimpulkan bahwa perlakuan A dan $\mathrm{C}$ menunjukkan hasil berbeda sangat nyata dilihat dari notasi sedangkan pada perlakuan B hasilnya menunjukkan tidak berbeda nyata. Berdasarkan hasil uji BNT (Tabel 6) menunjukkan bahwa pakan berupa cacing sutera (Tubifex sp.) menghasilkan laju pertumbuhan yang tertinggi, yang kemudian diikuti oleh perlakuan A yang menggunakan Artemia sp., sedangkan laju pertumbuhan terendah dihasilkan dari perlakuan B yang menggunakan Daphnia sp. Perlakuan $\mathrm{C}$ merupakan perlakuan dengan jenis pakan yang menghasilkan nilai rata-rata laju pertumbuhan tertinggi. Hal ini dikarenakan beberapa faktor antara lain kebiasaan makan.

Banyak faktor yang mempengaruhi perbedaan pertumbuhan ikan diantaranya adalah perbedaan habitat, kebiasaan makan, 
aktifitas ikan dan musim. Suhu, ketersediaan makanan dan tingkat trofik juga mempengaruhi pertumbuhan ikan (Lowem and Connel, 1987).

SGR (Specific growth rate) pada tiap spesies berbeda tergantung pada spesies dan ukuran ikan. SGR akan menurun seiring dengan meningkatnya ukuran tubuh. SGR sendiri terlihat banyak dipengaruhi oleh kandungan protein dalam pakan (Amoaah, 2011).

Cacing sutera mengandung protein paling tinggi dibandingakan dengan Artemia dan Daphnia yaitu 63,05 \% sehingga perlakuan yang menggunakan cacing sutera sebagai pakan menunjukkan SGR tertinggi dibandingkan perlakuan yang lain. Hal ini sesuai dengan yang diungkapkan oleh Zonneveld, et al. (1991) bahwa semua jenis ikan membutuhkan protein sebagai energi utama untuk tumbuh sebanyak 2 - 3 kali lebih tinggi dibandingkan hewan berdarah panas.

Lovell (1989) mengatakan bahwa nutrien utama yang mempengaruhi performa pertumbuhan ikan adalah protein. Protein menyediakan asam-asam amino esensial dan non esensial yang dibutuhkan untuk pembentukan otot dan fungsi enzimatik, selain itu protein juga bertugas untuk untuk menjaga ketersediaan energi (Yang, et al., 2002).

\section{Kualitas Air}

Kualitas air memegang peranan yang sangat penting dan harus diperhatikan dalam pemeliharaan ikan, karena sangat berpengaruh bagi kelangsungan hidup ikan tersebut. Beberapa parameter yang diamati dalam penentuan kualitas air selama penelitian adalah suhu, derajat keasaman $(\mathrm{pH})$ dan oksigen terlarut (DO).

Berdasarkan hasil pengukuran kualitas air, kisaran suhu pagi hari selama pemeliharaan berkisar antara $20{ }^{\circ} \mathrm{C}-24{ }^{\circ} \mathrm{C}$ dan sore hari 24 ${ }^{\circ} \mathrm{C}-27{ }^{\circ} \mathrm{C}$. Nilai tersebut masih bisa dikatakan sebagai nilai yang normal. Menurut Kordi dan Tancung (2005), pada suhu $>24{ }^{\circ} \mathrm{C}$ ikan Gabus akan mengalami pertumbuhan yang optimal sedangkan jika suhu perairan kurang dari $24{ }^{\circ} \mathrm{C}$ ikan Gabus tetap akan hidup, namun nafsu makan mulai turun dan akan menjadi kondisi yang menguntungkan untuk munculnya bakteri di perairan.

Selama penelitian, kandungan oksigen terlarut dalam akuarium berada dalam rentang $4,50 \mathrm{mg} / \mathrm{L}$, nilai ini bisa dikatakan masih dalam nilai yang layak untuk pertumbuhan ikan
Gabus, seperti yang dikemukakan oleh Muflikhah dkk., (2008) yaitu untuk pemeliharaan ikan Gabus kandungan oksigen terlarut yang diperlukan minimal adalah 3 $\mathrm{mg} / \mathrm{L}$.

Keberadaan oksigen terlarut dalam perairan sangat penting bagi kehidupan organisme air termasuk ikan Gabus. Oksigen terlarut dalam perairan akan digunakan untuk melakukan respirasi serta metabolisme, selain itu oksigen terlarut akan digunakan untuk dekomposisi bahan organik yang ada di dasar perairan atau kolam. Oksigen terlarut juga diperlukan ikan untuk melangsungkan pembakaran bahan makanan untuk menghasilkan aktifitas seperti berenang, pertumbuhan dan reproduksi (Zonneveld, et al., 1991).

Hasil pengukuran derajat keasaman $(\mathrm{pH})$ selama pemeliharaan berkisar antara $5-8,42$. Nilai tersebut masih dalam kisaran normal, seperti yang dikemukakan oleh Muflikhah dkk. (2008) yaitu $\mathrm{pH}$ yang baik untuk pemeliharaan benih ikan Gabus berkisar antara 4 - 9. Sama halnya seperti yang diungkapkan oleh Amoaah (2011) bahwa ikan secara umum sensitif terhadap perubahan $\mathrm{pH}$ air. Produktifitas yang tinggi akan dicapai dalam perairan dengan $\mathrm{pH}$ antara $6.5-8.5$.

\section{KESIMPULAN}

Dari hasil penelitian ini dapat disimpulkan sebagai berikut:

1. Perlakuan C (pakan cacing sutera) menghasilkan laju pertumbuhan panjang harian yang tertinggi yaitu sebesar 1,25 $\% /$ hari. Untuk laju pertumbuhan spesifik (SGR) juga dihasilkan dari pakan cacing sutera yaitu sebesar $1,39 \% /$ hari.

2. Kualitas air yang baik untuk pemeliharaan benih ikan Gabus adalah berada pada kisaran $20{ }^{\circ} \mathrm{C}-27{ }^{\circ} \mathrm{C}$, DO $3-4,50 \mathrm{mg} / \mathrm{L}$ dan pH pada kisaran 5-8,42.

\section{SARAN}

Perlu dilakukan penelitian lanjutan mengenai pemberian pakan menggunakan cacing sutra dengan dosis yang berbeda untuk mengetahui optimasi pertumbuhan ikan.

\section{DAFTAR PUSTAKA}

Amoaah, Yaa Tiwaah. 2011. Effect Of Dietary Protein Levels On Growth And Protein Utilization In Juvenile Arctic Char (Salvelinus alpinus). Final Project. 
Ministry of Food and Agriculture Fisheries Commission, Ashanti RegionGhana. United Nation University. Ghana.

Ansar, M. dan L, Muslimin. 2010. Pengolahan dan Pemanfaatan Ikan Gabus. Direktur Jendral Pendidikan Nonformal dan format. Jakarta. $65 \mathrm{hlm}$.

Bijaksana, U. 2010. Kajian Fisiologis Reproduksi Ikan Gabus Channa striata Blkr di dalam Wadah Perairan Rawa Sebagai Upaya Domestikasi. Disertasi. Program Pasca Sarjana Institut Pertanian Bogor. Tidak diterbitkan.

Craig, S. and Helfrich, L. A. 2009. Understanding fish nutrition, feeds and feeding. Virginia Cooperative. Extension Publication 420-256.

Jobling, M. 1994. Fish Bioenergetics. London: Chapman and Hall.

Kartamihardja, E. S. 1994. Biologi Reproduksi Populasi Ikan Gabus Channa striata di Waduk Kedungombo. Bull. Perikanan Darat. 12Q: 113-119.

Kordi, K. M. G. H. dan A. B Tancung. 2005. Paengelolaan Kualitas Air dalam Budidaya Perairan. Rineka Cipta. Jakarta. $37 \mathrm{hlm}$.

Lovell, R. T. 1989. Nutrition and feeding of fish. Van Nonstrand-Reinhold. New York: pp 260.

Lowem, C. and R. H. Connell. 1987. Ecological studies in tropical fish communities. Cambridge University Press. London. pp: 159-173.

Meyer, G. and Fracalossi, D. M. 2004. Protein requirement of jundia fingerlings, Rhmdia quelen, at two dietary energy concentration. Aquaculture. 240: 341343.

Mulyadi, M., T. Usman dan Suryani. 2010. Pengaruh Frekuensi Pemberian Pakan Yang Berbeda Terhadap Pertumbuhan dan Kelangsungan Hidup Benih Ikan Selais (Ompok hypophthalamus). Berkala Perikanan Terubuk. Volume. 38 No 2.
Muflikhah, N., M. Safran dan N. K. Suryati. 2008. Gabus. Balai Riset Perikanan Perairan Umum. 7 hlm.

Pangkey, H. 2009. Daphnia dan Penggunaanya. Jurnal Perikanan dan Kelautan. Vol. (3): 33-36.

Ulandari, A., D. Kurniawan dan A. S. Putri, 2011. Potensi Protein Ikan Gabus dalam Mencegah Kwashiorkor pada Balita di Provinsi Jambi. Universitas Jambi. Jambi. Hal. 6.

Yang, S. D. , C. H. Liou and F. G. Liu, 2002. Effects of dietary protein level on growth performance, carcass composition and ammonia excretion in juvenile silver perch (Bidyanus bidyanus). Aquaculture. 213: 363-372.

Zonneveld, N., E. A. Huisman dan J. H. Boon. 1991. Prinsip-Prinsip Budidaya Ikan. PT. Gramedia Pustaka. Jakarta. 318 hlm. 